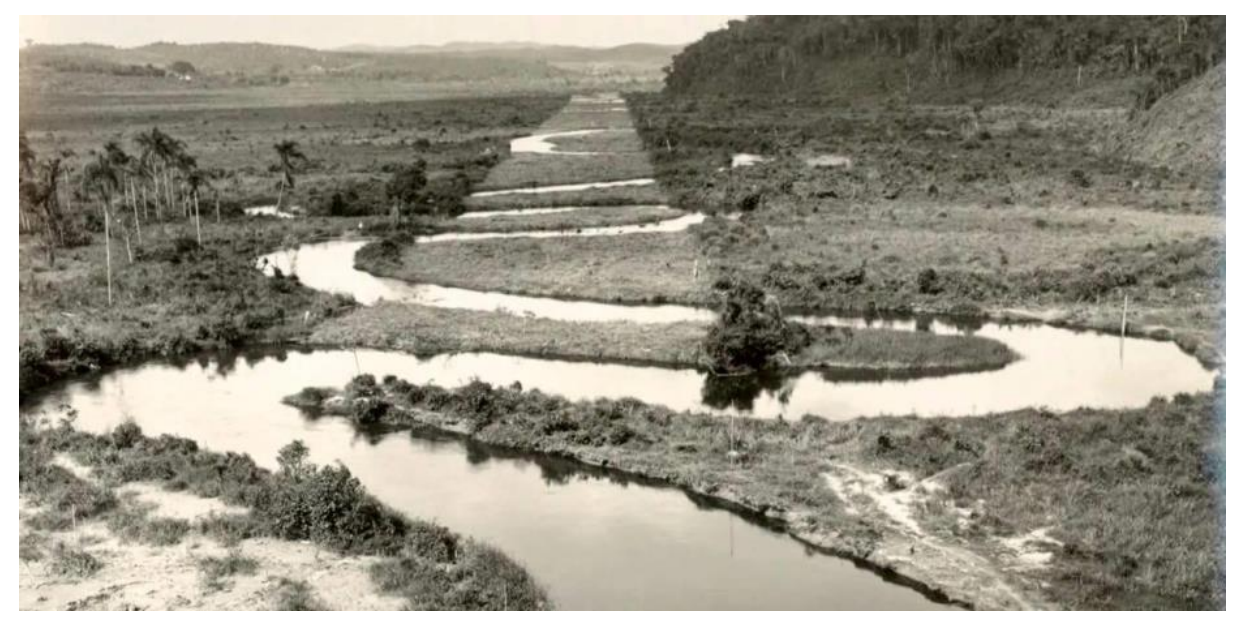

\title{
Geografia umbilical
}

Telma Domingues da Silva ${ }^{1}$

ORCID: https://orcid.org/0000-0002-0273-5786

As aulas de geografia na escola me situam primeiro ali pelo bairro em torno, falando do Rio Pinheiros e também do Córrego Pirajussara. O Pirajussara, que passava do lado da escola, sumiu, faz tempo já, deve estar debaixo da cidade.

Começo em Pinheiros: é lá que começa minha memória lembrada. Hoje tudo mudou mas tudo então já tinha mudado, antes desse meu começo. E, dessa mudança de antes dessa existência lembrada de mim mesma, me chega notícia pelo avô que dizia "está tudo diferente".

Meu avô foi barqueiro no Rio Pinheiros. Meu avô era português, analfabeto e tirava areia do leito do rio. Areia para a construção. Depois, ele teve uma olaria, mantendo-se na construção.

Não conheci esse rio, diferente, todo curvo, que oferecia nas curvas a possibilidade de um imigrante português tirar seu sustento. O rio Pinheiros que conheci era um rio fedido que eu criança tinha que atravessar para ir à escola; às vezes, cedo, eu o via de cima, pela janela do ônibus escolar, com uma neblina densa o cobrindo - isso no tempo em que as manhãs eram frias, trazendo vestígios da madrugada.

Rio Tiête, Rio Pinheiros, os dois grandes rios que ali mais na frente se cruzam e dão identidade à cidade. O rio Pinheiros não perdeu só suas curvas, na década de 1940,

\footnotetext{
${ }^{1}$ Professora do PPGCL da UNIVÁS. E- mail: tel-madds@ gmail.com.
} 
mas antes mesmo perdeu seu nome indígena "Jurubatuba", e eu demorei anos para saber desse outro nome perdido.

Pinheiros era um bairro de barqueiros e lavadeiras, li em algum lugar depois de velha, "como meus avós", pensei.

Minha avó, quando ia ao centro de São Paulo, dizia: "vou na cidade", resquício de um tempo em que Pinheiros não pertencia à "cidade", mas era um sítio não urbanizado. Quando conheci Pinheiros já não era assim, um território à parte da cidade, mas minha avó mantinha essa relação de deslocamento e, quando minha avó ia "na cidade", trazia haleu, que delícia!

Minha avó foi lavadeira no Rio Pinheiros: com seus 14 anos já lavava roupa para fora. Era portuguesa, veio menina com os pais e irmãos de Portugal. Pinheiros e sua vida em torno do rio uniu esse casal e minha mãe e tio nasceram desse casamento, sim, entre um barqueiro e uma lavadeira, portugueses, vivendo em Pinheiros.

Viveram antes de eu nascer numa casa de esquina na Gilberto Sabino. Conheci a casa como sendo casa da tiaAida, pois o irmão do vovô foi morar lá com a família quando meus avós mudaram e foram morar mais para cima (em referência ao rio), na rua Amaro Cavalheiro. Na casa da tiaAida tinha um pé de café no jardim da frente e uma parreira enorme cobrindo o quintal lateral, e quando dava uva os motoristas da empresa de ônibus Santa Cecília, a garagem ficava ali ao lado, roubavam cachos pelo muro. TiaAida, portuguesa desbocada, de seu quintal e de dentro de seu indispensável avental, berrava uns "caralhos que o fodam" aos homens, que riam dela.

Mas é para falar do rio que escrevo. Porque sinto ele como meu começo, como um reconhecimento necessário, como parte de uma existência cidadã não negada: é de lá que começo a ir a outros lugares, o Pinheiros é o umbigo da minha geografia. De lá vou à escola, em um dos primeiros movimentos, e de lá tenho notícia da "cidade" (o centro) e suas delícias.

Falando nisso, para ir à casa da TiaAida, eu ia em direção ao rio, descia a rua Capri e, na Gilberto Sabino, quando a rua era ainda de terra, eu lembro de atravessar uma pontezinha de madeira. Então, tinha um pequeno córrego, um fiozinho d'água sem nome, do lado da casa da Gilberto Sabino, cortando a rua, um outro córrego que também sumiu. Essa lembrança é muito, muito vaga, como que envolta em névoa, parecendo imagem de sonho ou parecendo um filme: uma travessia cuidadosa à noite ou entardecer, essa é a lembrança, em um pequeno grupo de pessoas, primas mais velhas, primas da minha mãe. Uma lembrança da qual duvido, como se fora inventada para dar lugar a uma travessia de 
outra ordem, algum trânsito perdido nesse tempo interno, mas é da ruína que se trata mesmo.

Meu avô fora barqueiro, antes da minha existência, e isso centraliza esse desenrolar, essa visitação de um território de águas insuspeitas, subterrâneas. Em algum momento de minha primeira infância, meu avô sofreu um derrame, hoje dizemos isquemia, e ficou com a fala prejudicada, difícil.

Meu avô pouco falava e o evento do derrame veio a calhar para a distância em relação aos afetos. Como fazem os avós, ele me pegava para um passeio, eu de mãos dadas com ele, aquele homem alto, de chapéu de feltro, e descíamos pela Capri, pela Gilberto Sabino, pela Sumidouro - o nome "Sumidouro" sempre me inquietou - em direção ao rio, para a estação de trem - que por sinal ainda está lá. Comumente, ele calado, eu buscando contato, querendo transpor o silêncio entre nós e, em meu próprio silêncio, ao buscar assuntos, inibida, testava a possível ressonância de minhas palavras.

Na minha ingenuidade, eu ia ver o trem. Não tinha a marginal Pinheiros, por isso era um passeio possível ir a pé ali à margem do rio, onde passa o trem. Eu ia à estação, ia ver o trem passar, parar, descer e subir gente: via com admiração que, em vagões parados ao lado do trilho principal, pessoas, famílias moravam, e pensava "que casa legal!".

Mas foi muito tempo depois, depois já de tê-lo perdido há tempos, que eu percebi que meu avô não ia ver o trem, mas ficar perto do rio. Naquela época eu não dava conta da força dessa presença, mas ela de alguma forma me constituiu. Está tudo diferente, a marginal afastará a possibilidade de uma aproximação do rio, muito embora o cheiro fosse suficiente.

Atravessada pela lembrança de meu avô dizendo irritado "está tudo diferente", fico imaginado o rio, o Pinheiros antes da "retificação", o rio cheio de curvas, rio não só para ser atravessado no automóvel ou ônibus, obstáculo do trânsito urbano, mas - como não amá-lo? - o rio para se banhar e se navegar, o rio rio 


\section{Para citar essa obra:}

SILVA, Telma Domingues da. Geografia umbilical. In: RUA [online]. Volume 27, número 2 - p. 467-469 - e-ISSN 2179-9911 - novembro/2021. Consultada no Portal Labeurb - Revista do Laboratório de Estudos Urbanos do Núcleo de Desenvolvimentoda Criatividade. http://www.labeurb.unicamp.br/rua/

Capa: Rio Pinheiros.

\section{Laboratório de Estudos Urbanos - LABEURB}

Núcleo de Desenvolvimento da Criatividade - NUDECRI

Universidade Estadual de Campinas - UNICAMP

http://www.labeurb.unicamp.br/

Endereço:

LABEURB - LABORATÓRIO DE ESTUDOS URBANOS

UNICAMP/COCEN / NUDECRI

CAIXA POSTAL 6166

Campinas/SP - Brasil

CEP 13083-892

Fone/ Fax: (19) 3521-7900

Contato: http://www.labeurb.unicamp.br/contato 